\title{
病院用エネルギ一供給システムの更新計画における初期システムの影響分析*
}

\author{
吉田 修"1, 吉田 涁 $^{* 2}$, 伊東 弘一 ${ }^{* 3}$, 天野 嘉春 ${ }^{* 4}$
}

\section{Influence of Initial Systems on the Renewal Planning of Energy Supply Systems for a Hospital}

\author{
Shu YOSHIDA ${ }^{* 1}$, Akira YOSHIDA, Koichi ITO and Yoshiharu AMANO \\ ${ }^{* 1}$ Energy Use Research and Development Center, The Kansai Electric Power Co., Inc. \\ 3-11-20 Nakoji, Amagasaki, Hyogo, 661-0974 Japan
}

In this study, a renewal planning problem of energy supply system is formulated as a large scale mixed-integer linear programming problem, in which the objective function to the minimized is the average value of annual total cost during system's evaluation period. By adopting the programming language AMPL and CPLEX solver, a numerical study is carried out for a hospital, where electrical(e.g., heat pump) and gas(e.g., gas engine cogeneration) systems are compared together with arbitrary combination one, which is composed of electrical and gas driven pieces of equipment, by focusing particularly on the influence of initial system's difference. The main results obtained are as follows: (a) If the initial system is gas one, it is better to renew it to the electrical one as soon as possible due to relatively low energy efficiency of gas utilizing pieces of equipment, the high price of gas input energy and so on. (b) If the initial system is electrical one, the optimal renewal year becomes relatively later year, because it is economically better to use the initially installed high efficiency system as long as possible. (c) Theoretically, the arbitrary combination system is of course the best renewal one. However, there is no economic difference between the arbitrary combination system and the electrical one.

Key Words : Systems Engineering, Energy Management, Engineering Optimization, Energy Supply Systems, Renewal Planning, Hospital

\section{1. 緒言}

近年，色々な建物に冷暖房や給湯のための各種エネルギー供給システムが導入されてきた。これらの建物の耐 用年数は一般に 60 年以上で，その長寿命化が図られている. その一方で，エネルギー供給システムの耐用年数は 約 15 25 年程度と相対的に短く，建物の寿命内に数回のシステム更新が実施されている.

上記エネルギー供給システムの計画問題に関しては，過去システムの新設計画に対する数学的最適化手法の導 入に関するいくつかの研究(1)(2)がなされている。しかしながら, システムの更新計画問題に関しては, その重要性 にもかかわらず理論的研究は過去ほとんどなされてこなかった．著者らは，これまでに事務所ビルにおけるエネ

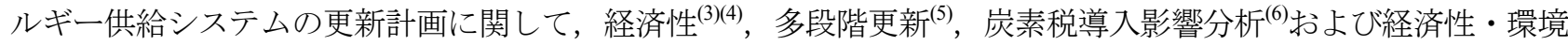

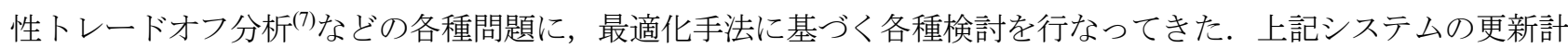
画問題においては, 既設機器類の性能劣化, 更新時新規導入候補機器群の技術開発に伴う性能向上などに加えて, 年間に渡り時々刻々変動する建物内エネルギー需要量に対するシステム運用問題を総合的に考慮しながら，シス テムの長期的経済性の視点から計画立案を行なっていくことが必要となる．上記計画の結果として，既存システ ムの不要あるいは効率の悪くなった機器類を撤去し，新たに技術進歩を反映した高効率な機器類をいつの時点で

\footnotetext{
* 原稿受付 2013 年 5 月 23 日

*1 正員, 関西電力 (株) 研究開発室エネルギー利用技術研究所（广 661-0974 兵庫県尼崎市若王寺 3-11-20)

*2 正員, 早稲田大学理工学術院基幹理工学研究科（广169-8555 東京都新宿区大久保 3-4-1）

*3 正員, フェロー，早稲田大学理工学術院総合研究所

*4 正員, 早稲田大学理工学術院総合研究所

E-mail: yoshida.shuu@e2.kepco.co.jp
} 
導入してシステムを更新することが経済性の観点から望ましいかという解が導出される.

ここで，上記問題において，建物内に既に設置されている既設システム（以下，初期システムと呼ぶ）の相異 が，更新計画の解に大きく影響を及ぼすことが予想される．何故ならば，例えば初期システムに高価で高効率な 機器類が導入されていても, 急いで更新が実施される可能性は多分低いであろうし, またその逆の結果も予想さ れるからである.

本研究の目的は, 建物用エネルギー供給システムの更新計画問題において, 過去検討がなされてこなかった初 期システムの相異に関する影響の分析・評価を行うことである．以下では，システムの評価期間内における平均 年間総経費を目的関数とする最適計画問題を構成する. 事務所ビルと異なってより構造が複雑となる病院に対し て，初期システムの相異が更新計画問題に与える影響を数值的に検討する.

\section{主要記号}

C : 年間設備費 $[$ yen/year]

E : 電気式システム

$G \quad$ : ガス式システム

$H \quad$ : 電気・ガス併用式システム

$i \quad:$ 金利 $[\% /$ year $]$

$J \quad ：$ システム評価期間平均年間総経費 [yen/year]

$M \quad$ : 年間メンテナンス費 [yen/year]

$O \quad$ : 年間運用費 $[$ yen/year]

$\boldsymbol{P} \quad$ : 機器性能特性対角行列

$S \quad$ : スタンダード式システム

$t \quad$ : 経過年変数 [year]

$t_{\mathrm{p}}:$ 更新計画立案年 [year]

$T \quad$ : システム評価期間 [year]

$\boldsymbol{u}, \boldsymbol{v} \quad$ : 構成機器入・出力流量ベクトル $[\mathrm{kWh} / \mathrm{h}]$

: 機器容量ベクトル $[\mathrm{kW}]$

: 初期システム

: 更新システム

: 電力・ガス最大契約流量ベクトル $\left[\mathrm{kW}, \mathrm{Nm}^{3} / \mathrm{h}\right]$

$Y_{1} \quad$ : 新規導入候補機器群

$\boldsymbol{\alpha} \quad$ : 機器性能特性向上率ベクトル [\%/year]

$\boldsymbol{\beta} \quad$ : 機器性能特性劣化率ベクトル [\%/year]

$\gamma \quad$ : 機器設備据付工事費用比率

$\boldsymbol{\delta} \quad$ : 機器選択 0-1 整数変数ベクトル

$\varepsilon \quad:$ 機器法定耐用年数時残存価值率

$\theta \quad$ : 機器耐用年数経過後メンテナンス費増加率

$\kappa \quad$ : 機器法定耐用年数 [year]

$\lambda$ : システム導入時エネルギー需要種別機器設備余裕率

$\mu \quad$ : 機器設備撤去工事費用比率 
$\tau$ : システム更新年 [year]

\section{機器記号}

BS

: 蒸気ボイラ

$\mathrm{CH} \quad$ : 水冷スクリュー式冷凍機

EW : 給湯用空冷スクロール式ヒートポンプ

EWT : ヒートポンプ用貯湯槽

GE : :ガスエンジン

GL : 排熱投入型ガス吸収式冷温水機

HB : 空冷ブラインスクリュー式ヒートポンプ

HP : 空冷スクリュー式ヒートポンプ

HWT : 貯湯槽

IST : 水蓄熱槽

$\mathrm{RE} \quad$ : 水冷ターボ冷凍機

RG : ガス吸収式冷温水機

RS : 蒸気吸収式冷凍機

\section{2. 最適更新計画問題}

\section{$2 \cdot 1$ 計画問題の概要}

図 1 は, 最適更新計画問題の概要を示したものである. 図中, 横軸 $t$ は経過年数を表し, 初期システム $X_{0}$ は $t=0$ [year] で設置される. システムの更新計画立案年は現時点の $t=t_{\mathrm{p}}$ [year] であり，システムの評価期間は $t=t_{\mathrm{p}} \sim t=t_{p}+T$ で, その長さを $T$ [year] とする. 初期システム $X_{0}$ は更新年 $t=\tau$ [year] $\left(t_{\mathrm{p}} \leq \tau \leq t_{\mathrm{p}}+T\right)$ におい て, 更新システム $X_{1}$ に更新されるものとする. 図 1 に示すように, 更新においては $X_{0}$ 中の効率が低くて不要にな ったいくつかの既設機器類が撤去され，新たに効率の高い新規導入候補機器群 $Y_{1}$ の中から適切な機器が選定され て導入され， $X_{1}$ が構成される.

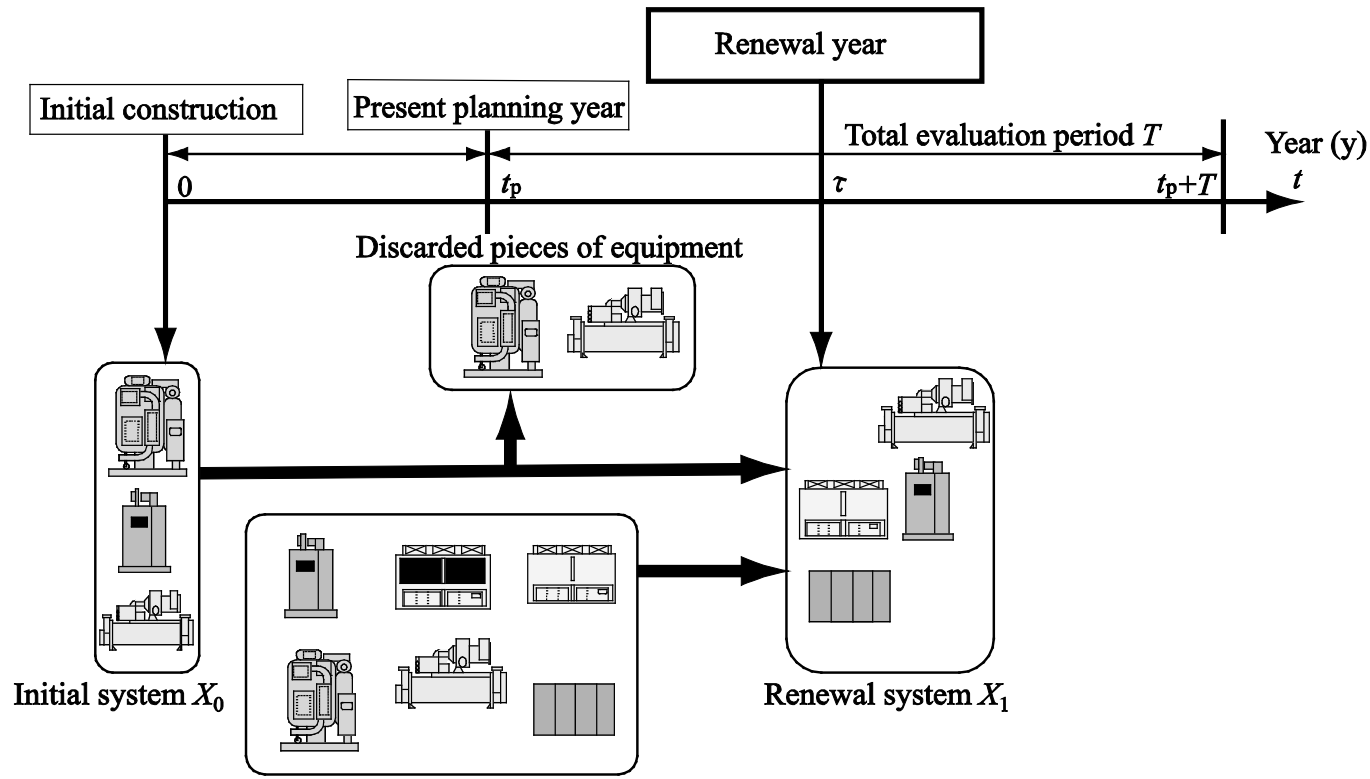

Set of candidate pieces of equipment installed newly $Y_{1}$

Fig. 1 Framework of the renewal planning problem 


\section{$2 \cdot 2$ 数学的定式化}

\section{$2 \cdot 2 \cdot 1$ 決定変数および制約条件}

最適更新計画問題における決定変数は, 連続変数および 0-1 整数変数が混在し, 以下のようなものが含まれる. 連続変数の中には，更新時における新規導入機器容量 $\boldsymbol{x}$, システムの運用に関する各構成機器入・出力エネルギ 一流量ベクトル $\boldsymbol{u}$ およびv, ならびにシステムへの入力エネルギーとしての電力およびガスの最大契約流量ベクト ル $\boldsymbol{y}$ が含まれる. 0-1 整数変数としては, $X_{1}$ の構成における $X_{0}$ の機器の存続または撤去および $Y_{1}$ の機器の導入また は非導入に関連する機器選択変数べクトル $\boldsymbol{\delta}$ である. ここで, $Y_{1}$ の機器群は, 機種毎に異なるものの初期システム 導入時点 $(t=0)$ から線形的に $\alpha[\% /$ year $]$ 割合で性能特性が向上するものと仮定する．その一方で，既設または新 規導入機器群は，機種毎にかつ $t=0$ から線形的に $\beta[\% / y e a r]$ 割合で性能特性が劣化していくものとする.

本研究においては，建物内におけるエネルギ一需要量は，時間および月毎に変動するものとしたが，評価期間 内における年毎の変動は無いものとした．ただし，前述の機器類の性能劣化率 $\beta$ を映して，システムの運用方

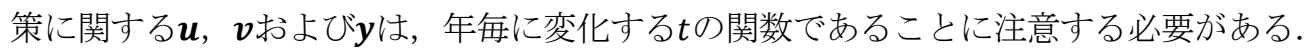

次に，最適化問題における制約条件としては，まず次式に示す機器性能特性に関するものである.

$$
\begin{aligned}
& \boldsymbol{v}=\boldsymbol{P} \cdot \boldsymbol{u} \\
& 0 \leq \boldsymbol{v} \leq \boldsymbol{x}
\end{aligned}
$$

式(1)のPは対角行列であり, 式(2)の機器容量ベクトル $\boldsymbol{x}$ と共に機器性能特性の劣化率 $\beta$ を反映して $t$ の関数であ る. また， $Y_{1}$ からの新規機器導入の検討に関するPの要素の值は，性能特性向上率 $\alpha$ 反映したものになる.

次の制約条件としては，エネルギー供給システムの各機器結合・分岐点におけるエネルギー・バランス式に加 えて，エネルギー需給関係式がある，最後に，電力およびガスの購入流量が最大契約流量 $\boldsymbol{y}$ 以下であるという制 約条件を考慮しなければならない.

\section{$2 \cdot 2 \cdot 2$ 目的関数}

最適化問題における最小化すべき目的関数としては，図 1 に示す評価期間 $T$ 内における年間総経費の平均值を 取り上げる. この值は，年価法 ${ }^{(8)}$ に基づいて図 2 に示すように年間における設備費，運用費およびメンテナンス 費の総和として次式で算出される.

$$
J=C(\boldsymbol{\delta}, \boldsymbol{x})+O(\boldsymbol{y}, \boldsymbol{x})+M(\boldsymbol{x}, \boldsymbol{u})
$$

上式の年間設備費 $C$ は，システム新設時 $(t=0)$ おび更新時 $(t=\tau)$ においてそれぞれ発生する新設設備費および設 備更新費（不要となった新設時機器撤去費, 新規導入機器設備費および据付工事費を含む）の関数として表わさ れる.ここで, 更新時における新規導入機器設備費は機器選択 0-1 整数変数ベクトル $\boldsymbol{\delta}$ おび機器容量ベクトル $\boldsymbol{x}$ の 関数である.さらに，上述の機器撤去費および据付工事費は，各機器容量 $\boldsymbol{x}$ に機器設備撤去および据付工事費用

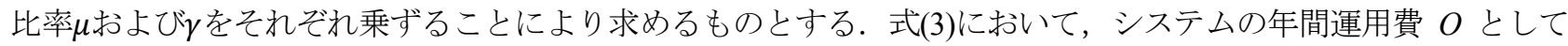
は，入力エネルギー費のみを算定し，人件費などはここでは考慮しないものとする．なお，入力エネルギー費の 中には電力およびガス料金の他に，冷却水用水道料金を含めるものとする． $O$ は，入力エネルギー流量ベクトル $\boldsymbol{u}$ と最大契約流量ベクトル $\boldsymbol{y}$ の関数となるが， $\boldsymbol{u}$ はエネルギー需要量の変動に対応して時間および月毎に変わるこ とに加えて, 前述したように機器の劣化の影響を反映して $t$ により変動し, 複雑な関係式となる.また式(3)中の $M$ は 年間メンテナンス費であり, $\boldsymbol{x}$ と潂の関数として表される.

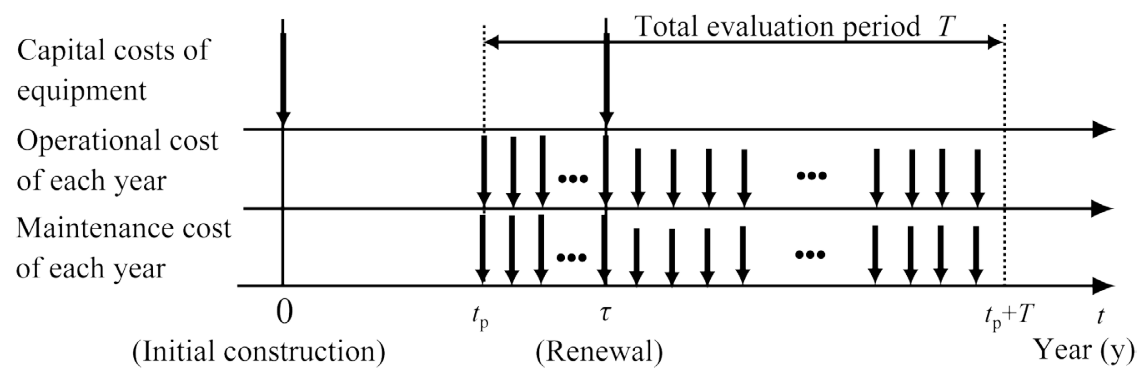

Fig. 2 Economic evaluation of the renewal system 
言及するまでも無いが，年価法の計算においては金利 $i$ [\%/year]およびシステムの評価期間の終了時点におけ る機器類の残存価值の考慮が必要になる. 後者に関しては, 次章の数值計算においては, 各機器の法定耐用年数 を機種によらずすべて一定で $\kappa$ [year] とし，また耐用年数後の残存価值率を一定のととした．なお，各機器は法定 耐用年数 $\kappa$ 後も使用可能としたが, その際 $\theta$ を機器耐用年数経過後メンテナンス費増加率として $(1+\theta)$ 倍のメンテ ナンス費が必要であるものとした。ここで，図 2 に示した新設時に発生した設備費と，更新時に必要となる設備 費の評価期間 $T$ 内の年間設備費 $C$ 一の換算において, 新設システムの設備費は基本的に $t=t_{\mathrm{p}} \sim \tau$ の期間内で, また新設システムの設備費は $t=\tau \sim t_{\mathrm{p}}+T$ の期間内で評価されることになる.ただし，更新システムは撤去さ れなかった新設システム機器群と, 更新時に新規に導入された機器群で構成されるため, 上述の換算における関 係式は非常に複雑なものとなる.

最後に，本論文で取り上げたエネルギー供給システムの計画立案においては，構成機器類の経過年数による性 能特性の劣化や, エネルギー需要量の不確実性などを考慮して, 一般に機器設備余裕率を考慮することが必要で ある. ここでは, システム導入時における機器設備余裕率をエネルギー需要量の種類別に考慮したが, 次章の数 值計算においてはこれらの值はすべて同じ值入であるものとした．なお，これらの単純化の仮定をはずしてより 複雑な条件に設定して数值解を求めることは, 基本的には可能である.

\section{$2 \cdot 2 \cdot 3$ 数値計算法}

$2 \cdot 2 \cdot 1$ および $2 \cdot 2 \cdot 2$ 項で述べた最適更新計画問題は, 大量の $0-1$ 整数変数と連続変数および制約条件式を 含む非常に大規模な混合整数線形計画問題(9)に帰着する. 本研究では分枝限定法と線形計画法におけるシンプレ ックス法を活用した AMPL/CPLEX ${ }^{(10)}$ を採用して，上記問題に対する数值解を導出した.

\section{3. 病院に対する数値分析・評価}

\section{$3 \cdot 1$ 入カデータ}

本研究では, 延床面積 $25000\left[\mathrm{~m}^{2}\right]$ の病院を数值計算事例として取り上げる. まず, 建物内の電力・冷房・暖房・ 給湯用エネルギー需要量を, 実測值などに基づいて設定する。年間に渡るこれらの需要量を, 各月の 1 時間毎の 平均值および各需要量の年間最大日における 1 時間毎の值で集約するものとする.一例として, 図 3 に 2 月およ び 8 月平均值を示す.

初期システム $X_{0}$ としては，ここでは 4 種類の異なるタイプのシステムを比較検討する. すなわち，スタンダー ドシステム $\left(X_{0}=S_{0}\right)$, ガス式システム $\left(G_{0}\right)$, 電気式システム $\left(E_{0}\right)$ および電気・ガス併用式システム $\left(H_{0}\right)$ である. $S_{0}$ は, 考察の対象とする病院に実在するシステムで, 4 つのシステムの比較基準として取り上げる. 表 1 に示すように, $S_{0}$ はガスエンジン $(\mathrm{GE})$, 蒸気吸収式冷凍機( RS), 蒸気ボイラ(BS)および貯湯槽(HWT)で構成されたシステムであ る. また, $X_{0}=G_{0}$ は $\mathrm{GE}$, 排熱投入型ガス吸収式冷温水機 $(\mathrm{GL})$, ガス吸収式冷温水機 $(\mathrm{RG})$ および $\mathrm{HWT}, X_{0}=E_{0}$ は水 冷ターボ冷凍機 $(\mathrm{RE})$, 空冷スクリュー式ヒートポンプ(HP), 給湯用空冷スクロール式ヒートポンプ(EW)およびヒ ートポンプ用貯湯槽(EWT), $X_{0}=H_{0}$ は RS, BS, 水冷スクリュー式冷凍機(CH), HP および HWT で構成されて いる. なお, 表 1 に各システムの構成機器の容量が示されているが, これらの值はシステムとしての供給能力が 各エネルギー需要量に対し等しくなるように, 最適化手法(1)に基づき設定したものである.

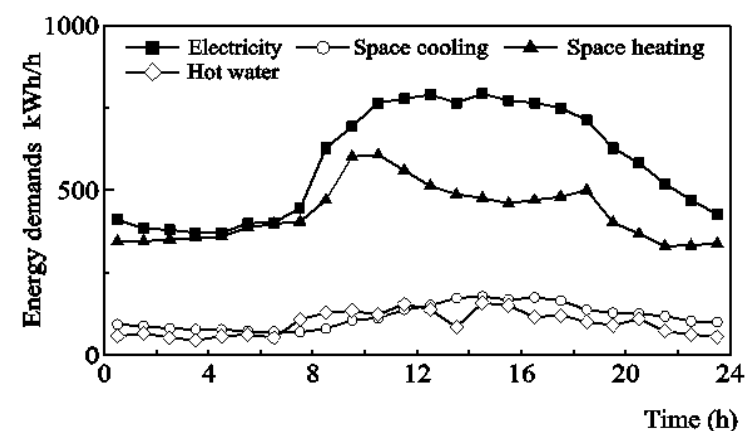

(a)

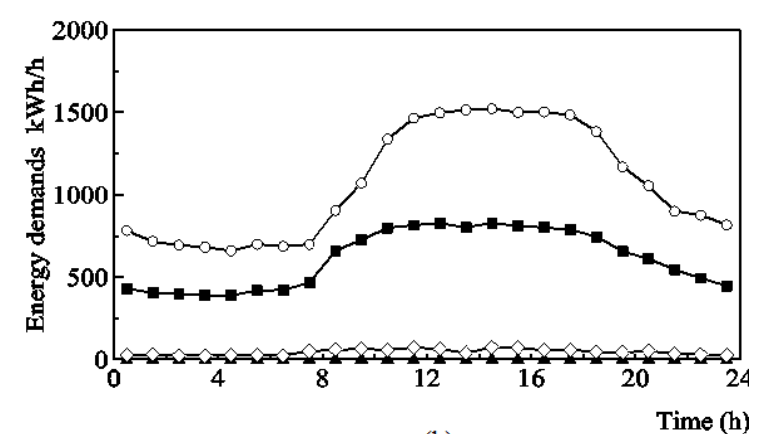

(b)

Fig. 3 Examples of hourly energy demands: a) February, b) August (Average demand days) 
更新計画問題においては，まず更新システムのスーパー・ストラクチュアを図 4 のように設定する. 図中，HB は空冷ブラインスクリュー式ヒートポンプであり, また IST は水蓄熱槽である. 現時点の更新計画年を $t_{\mathrm{p}}=7$ [year] と設定し, 考察の対象とする 4 つの初期システム $X_{0}=S_{0}, G_{0}, E_{0}$ および $H_{0}$ は, 図 1 に示すようにそれぞ れ異なる更新年 $t=\tau$ において, 更新システム $X_{1}$ に更新されるものとする. 寸なわち, $2 \cdot 1$ 節で述べたように, 更新年において $X_{0}$ からいくつかの機器類が撤去され, さらに新規導入候補機器群 $Y_{1}$ から選定された新規導入機器

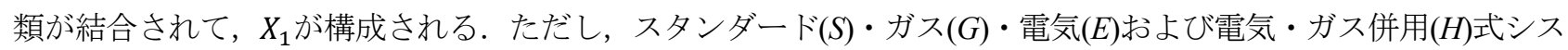
テムに対して，それぞれ $Y_{1}$ は表 1 の・印で示すような機器類に限定されているものとする. 本研究においては, 表 2 に示寸ようないくつかの更新計画問題を比較検討した. 一例として, $G_{0}-E_{1}$ は初期システム $X_{0}$ が表 1 に示寸 $G_{0}$ で, $Y_{1}$ が $E_{1}$ と仮定したケースである. 表 2 中の $S_{0}-S_{1}$ は, $X_{0}=S_{0}$ で，また $X_{1}$ の構成機器類およびそれらの機 器容量がすべて $S_{0}$ に等しく, さらに更新年が $\tau=15$ [year] で実施されるものと仮定したケースで, 各種の更新計 画問題における比較分析の基準として採用する.

Table 1 Alternative energy supply systems compared

\begin{tabular}{|c|c|c|c|c|c|c|c|c|c|}
\hline \multirow[b]{2}{*}{ Equipment } & \multicolumn{5}{|c|}{ Initial system $X_{0}$} & \multicolumn{4}{|c|}{ Candidate equipment $Y_{l}$} \\
\hline & $S_{0}$ & & $G_{0}$ & $E_{0}$ & $H_{0}$ & $S_{1}$ & $G_{1}$ & $E_{1}$ & $H_{1}$ \\
\hline GE & ○ $341[\mathrm{~kW}]$ & & $341[\mathrm{~kW}]$ & & & $\bullet$ & & & $\bullet$ \\
\hline $\mathrm{RS}$ & $\circ 2780[\mathrm{~kW}]$ & & & & $\circ 1293[\mathrm{~kW}]$ & $\bullet$ & $\bullet$ & & $\bullet$ \\
\hline $\mathrm{BS}$ & ○ $3310[\mathrm{~kW}]$ & & & & ○ $1078[\mathrm{~kW}]$ & $\bullet$ & $\bullet$ & & $\bullet$ \\
\hline GL & & & $783[\mathrm{~kW}]$ & & & & $\bullet$ & & $\bullet$ \\
\hline $\mathrm{RG}$ & & & $993[\mathrm{~kW}]$ & & & & $\bullet$ & & $\bullet$ \\
\hline RE & & & & $\circ 1340[\mathrm{~kW}]$ & & & & $\bullet$ & $\bullet$ \\
\hline $\mathrm{CH}$ & & & & & ○ $754[\mathrm{~kW}]$ & & & $\bullet$ & $\bullet$ \\
\hline HP & & & & $\circ 1435[\mathrm{~kW}]$ & ○ $729[\mathrm{~kW}]$ & & & $\bullet$ & $\bullet$ \\
\hline HB & & & & & & & & $\bullet$ & $\bullet$ \\
\hline EW & & & & ○ $302[\mathrm{~kW}]$ & & & & $\bullet$ & $\bullet$ \\
\hline IST & & & & & & & & $\bullet$ & $\bullet$ \\
\hline EWT & & & & ○ 2114 [kWh] & & & & $\bullet$ & $\bullet$ \\
\hline HWT & $\circ \quad 600[\mathrm{kWh}]$ & ० & $600[\mathrm{kWh}]$ & & ○ $600[\mathrm{kWh}]$ & $\bullet$ & $\bullet$ & & $\bullet$ \\
\hline
\end{tabular}

$\circ$ initially existing equipment

- candidate equipment installed newly

Table 2 Several cases of renewal plans compared

\begin{tabular}{|c|c|c|c|c|c|}
\hline Case & $\begin{array}{l}\text { Initial } \\
\text { system } X_{0}\end{array}$ & $\begin{array}{l}\text { Candidate } \\
\text { equipment } Y_{1}\end{array}$ & Case & Initial system $X_{0}$ & $\begin{array}{l}\text { Candidate } \\
\text { equipment } Y_{1}\end{array}$ \\
\hline$S_{0}-S_{1}$ & Standard & Standard & $E_{0}-G_{1}$ & Electrical & Gas \\
\hline$S_{0}-G_{1}$ & Standard & Gas & $E_{0}-E_{1}$ & Electrical & Electrical \\
\hline$S_{0}-E_{1}$ & Standard & Electrical & $E_{0}-H_{1}$ & Electrical & Arbitrary combination \\
\hline$S_{0}-H_{1}$ & Standard & Arbitrary combination & $H_{0}-G_{1}$ & Arbitrary combination & Gas \\
\hline$G_{0}-G_{1}$ & Gas & Gas & $H_{0}-E_{1}$ & Arbitrary combination & Electrical \\
\hline$G_{0}-E_{1}$ & Gas & Electrical & $H_{0}-H_{1}$ & Arbitrary combination & Arbitrary combination \\
\hline$G_{0}-H_{1}$ & Gas & Arbitrary combination & & & \\
\hline
\end{tabular}


表 3 に採用した電力・ガス料金体系および水道料金単価を示す. また, 表 4 に, 各機器の $t=0$ [year] におけ る設備費単価およびメンテナンス費単価と, 機器性能特性值およびそれらの向上率・劣化率をそれぞれ示す。こ れらの向上率および劣化率に関しては, 謝辞で述べた約 20 名のメーカー等の専門家集団が参加した部会におい て, 基本的に過去の実績データを調査分析し, 将来のテクノロジーアセスメント的予測に関する検討を加えなが ら設定したものである.さらに，表 5 に示すように，各機器法定耐用年数 $\kappa=15$ [year] ，金利 $i=3$ [\%/year] お よびシステム評価期間 $T=15$ [year] などと設定した.

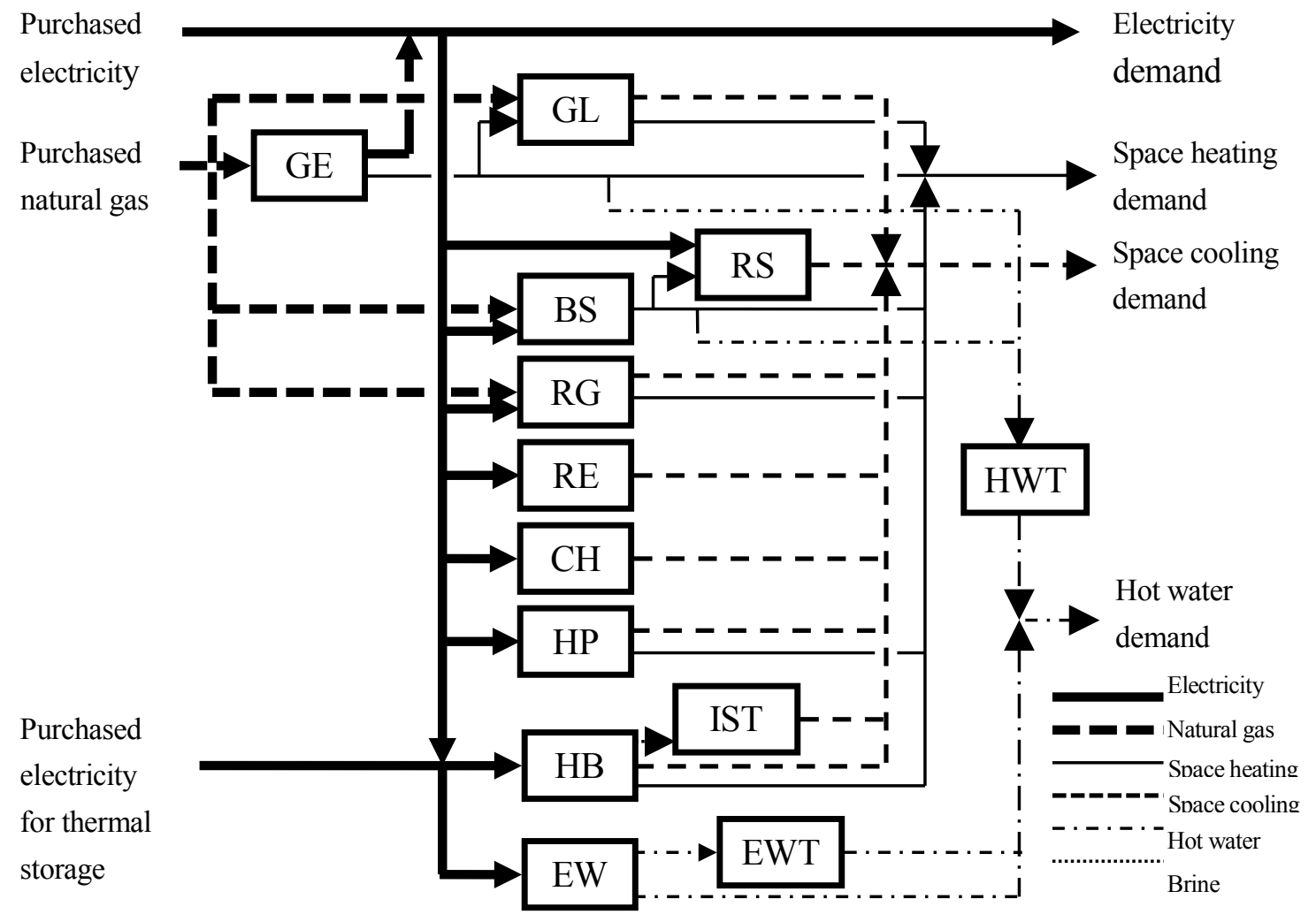

Fig. 4 Superstructure of renewal system

Table 3 Rates of purchased electricity and natural gas (Kansai Area, 2012)

\begin{tabular}{|c|c|c|c|c|}
\hline Utility unit cost & Customer charge & Demand charge & Maximum demand charge & Energy charge \\
\hline \multirow[t]{2}{*}{ Electricity } & - & 1.69 & - & (July Sep.) 12.67 [yen/kWh] \\
\hline & & {$\left[\times 10^{3} \mathrm{yen} /(\mathrm{kW} \cdot \mathrm{month})\right]$} & & (Other months) $11.65[$ yen $/ \mathrm{kWh}]$ \\
\hline \multirow{2}{*}{$\begin{array}{l}\text { Electricity for thermal } \\
\text { storage }\end{array}$} & - & - & - & $(22: 00 \sim 8: 00) \quad 5.94[$ yen $/ \mathrm{kWh}]$ \\
\hline & 25.4 & 1334 & $(7: 00 \sim 10: 00) \quad 9.74$ & $79.31\left[\right.$ yen $\left./ \mathrm{Nm}^{3}\right]$ \\
\hline \multirow[t]{3}{*}{ Natural gas } & {$\left[\times 10^{3}\right.$ yen/month $]$} & [yen $/ \mathrm{Nm}^{3} \cdot$ month] & [yen $/ \mathrm{Nm}^{3} \cdot$ month] & \\
\hline & & & $(10: 00 \sim 7: 00) \quad 4.96$ & \\
\hline & & & [yen $/ \mathrm{Nm}^{3} \cdot$ month] & \\
\hline Natural gas for & 8.62 & 912 & (Dec. $\sim$ Mar.) & $76.77\left[\right.$ yen $\left./ \mathrm{Nm}^{3}\right]$ \\
\hline cogeneration & {$\left[\times 10^{3}\right.$ yen/month $]$} & [yen $/ \mathrm{Nm}^{3} \cdot$ month] & $1.33\left[\right.$ yen $/ \mathrm{Nm}^{3} \cdot$ month] & \\
\hline Water & - & - & - & $550\left[\right.$ yen $\left./ \mathrm{m}^{3}\right]$ \\
\hline
\end{tabular}


Table 4 Economic and performance values of equipment (at $t=0$ )

\begin{tabular}{|c|c|c|c|c|c|c|c|}
\hline \multirow[t]{2}{*}{$\begin{array}{l}\text { Equip- } \\
\text { ment }\end{array}$} & \multicolumn{2}{|l|}{$\begin{array}{l}\text { Performance } \\
\text { characteristic } \\
\text { value }\end{array}$} & \multirow[t]{2}{*}{$\begin{array}{l}\text { Performance } \\
\text { improvement rate } \\
\text { of equipment } \\
\quad \alpha \quad[\% / \text { year }]\end{array}$} & \multirow[t]{2}{*}{$\begin{array}{l}\text { Performance } \\
\text { deterioration rate } \\
\text { of equipment } \\
\quad \beta \quad[\% / \text { year }]\end{array}$} & \multicolumn{2}{|c|}{$\begin{array}{l}\text { Capital unit cost } \\
a\left[\times 10^{3} \text { yen } / \mathrm{kW}\right] \\
+b\left[\times 10^{6} \text { yen }\right]\end{array}$} & \multirow[t]{2}{*}{$\begin{array}{l}\text { Maintenance } \\
\text { unit cost } \\
\text { [yen/(kW·year)] }\end{array}$} \\
\hline & & & & & $a$ & $b$ & \\
\hline \multirow[t]{2}{*}{ GE } & Power efficiency & 0.31 & 0.0 & 0.50 & 181 & 0.0 & $3.20^{\# 1}$ \\
\hline & Thermal efficiency & 0.45 & 0.0 & 0.0 & & & \\
\hline $\mathrm{RS}$ & $\mathrm{COP}$ & 1.29 & 0.75 & 1.50 & 12.4 & 7.76 & 1534 \\
\hline BS & Thermal efficiency & 0.88 & 0.0 & 0.25 & 3.48 & 0.420 & 706 \\
\hline \multirow[t]{3}{*}{ GL } & Thermal efficiency (space cooling) & 1.33 & 0.75 & 1.50 & 20.5 & 9.10 & 1600 \\
\hline & $\begin{array}{l}\text { Thermal efficiency (space cooling: } \\
\text { waste heat usage) }\end{array}$ & 1.81 & 0.75 & 1.50 & & & \\
\hline & Thermal efficiency (space heating) & 0.88 & 0.75 & 1.50 & & & \\
\hline \multirow[t]{2}{*}{ RG } & Thermal efficiency (space cooling) & 1.32 & 0.75 & 1.50 & 19.1 & 7.14 & 1534 \\
\hline & Thermal efficiency (space heating) & 0.88 & 0.0 & 0.0 & & & \\
\hline $\mathrm{RE}$ & $\mathrm{COP}$ & 6.12 & 1.00 & 0.50 & 18.4 & 15.8 & 1230 \\
\hline $\mathrm{CH}$ & $\mathrm{COP}$ & 5.45 & 1.00 & 0.50 & 23.5 & 1.01 & 1883 \\
\hline \multirow[t]{2}{*}{$\mathrm{HP}$} & COP (space cooling) & 4.30 & 1.50 & 0.50 & 39.8 & 0.0 & 1422 \\
\hline & COP (space heating) & 3.50 & 1.50 & 0.50 & & & \\
\hline \multirow[t]{3}{*}{ HB } & COP (brine for thermal storage) & 3.35 & 1.50 & 0.50 & 90 & 1.11 & 2161 \\
\hline & COP (space cooling) & 3.97 & 1.50 & 0.50 & & & \\
\hline & COP (space heating) & 3.22 & 1.50 & 0.50 & & & \\
\hline \multirow[t]{2}{*}{ EW } & COP (supplying hot water to tank) & 4.10 & 1.50 & 0.50 & 120 & 0.0 & 1422 \\
\hline & COP (supplying hot water directly) & 1.86 & 1.50 & 0.50 & & & \\
\hline IST $^{\# 2}$ & Thermal loss $(\% / h)$ & 1.0 & 0.0 & 0.0 & & & \\
\hline $\mathrm{EWT}^{\# 2}$ & Thermal loss $(\% / \mathrm{h})$ & 1.0 & 0.0 & 0.0 & & & \\
\hline HWT & Thermal loss $(\% / h)$ & 1.0 & 0.0 & 0.0 & $5.89^{\# 1}$ & 0.0 & 0 \\
\hline
\end{tabular}

${ }^{\# 1}$ yean $/ \mathrm{kWh}$

${ }^{\# 2}$ The capital initial and maintenance costs of IST and EWT are included in HB and EW, respectively.

Table 5 Values of miscellaneous parameters

\begin{tabular}{|c|c|c|c|c|c|}
\hline Item & Symbol & Value & Item & Symbol & Value \\
\hline Present planning year & $t_{\mathrm{p}}$ & 7 [year] & Surplus rate of system's capacity & $\lambda$ & 0.3 \\
\hline Total evaluation period of the system & $T$ & 15 [year] & Construction cost ratio of equipment & $\gamma$ & 0.4 \\
\hline Interest rate & $i$ & $3[\% /$ year $]$ & Discarding cost ratio of equipment & $\mu$ & 0.2 \\
\hline Residual cost ratio of equipment & $\varepsilon$ & 0 & \multirow{2}{*}{$\begin{array}{l}\text { Increasing rate of maintenance cost after the } \\
\text { end of statutory useful lifetime of equipment }\end{array}$} & \multirow{2}{*}{$\theta$} & \multirow[t]{2}{*}{0.2} \\
\hline Statutory useful lifetime of equipment & $\kappa$ & 15 [year] & & & \\
\hline
\end{tabular}




\section{$3 \cdot 2$ 数值計算結果および考察}

まず, 表 2 の更新計画問題の 13 の検討ケースの最適解について, 評価期間における年間設備費（機器設備費お よびそれらの撤去・据付工事費を含む)，年間メンテナンス費および電力・ガス・水道料金の平均值を，図 5 に示 す．また表 6 に，上記各ケースに対する最適更新年 $\tau=\tau^{*}$, 年間設備費・運用費およびメンテナンス費および総 経費の平均值と, 最適更新システムの機器構成（機種および容量）を示す.

Table 6 The structure of the renewal system for each optimal renewal plan [kW]

\begin{tabular}{|c|c|c|c|c|c|c|c|c|c|c|}
\hline \multirow{2}{*}{\multicolumn{2}{|c|}{ Case }} & $S_{0}-S_{1}$ & $S_{0}-G_{1}$ & $\begin{array}{l}S_{0}-E_{1} \\
\&\end{array}$ & $G_{0}-G_{1}$ & $\begin{array}{l}G_{0}-E_{1} \\
\&\end{array}$ & $E_{0}-G_{1}$ & $\begin{array}{l}E_{0}-E_{1} \\
\&\end{array}$ & $H_{0}-G_{1}$ & $\begin{array}{l}H_{0}-E_{1} \\
\&\end{array}$ \\
\hline & & & & $S_{0}-H_{1}$ & & $G_{0}-H_{1}$ & & $E_{0}-H_{1}$ & & $H_{0}-H_{1}$ \\
\hline \multicolumn{2}{|c|}{ Optimal renewal year $\tau^{*}$} & 15 & 9 & 7 & 13 & 7 & - & 18 & - & 13 \\
\hline \multicolumn{2}{|c|}{ Annual total $\operatorname{cost}^{\# 1}$} & 170.6 & 158.8 & 133.1 & 156.1 & 134.4 & 125.9 & 125.7 & 126.4 & 125.1 \\
\hline \multicolumn{2}{|c|}{ Annual capital cost ${ }^{\# 1}$} & 14.6 & 14.7 & 23.0 & 11.0 & 24.3 & 9.5 & 10.0 & 5.5 & 9.2 \\
\hline \multicolumn{2}{|c|}{ Annual operational cost ${ }^{\# 1}$} & 142.3 & 136.4 & 105.3 & 138.5 & 105.3 & 111.8 & 110.9 & 115.1 & 110.5 \\
\hline \multicolumn{2}{|c|}{ Annual maintenance cost ${ }^{\# 1}$} & 13.7 & 7.7 & 4.8 & 6.6 & 4.8 & 4.6 & 4.8 & 5.8 & 5.4 \\
\hline \multirow{28}{*}{ 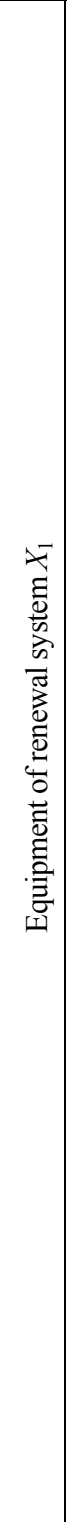 } & \multicolumn{10}{|l|}{ Initially existing equipment } \\
\hline & GE & dis. $^{\# 2}$ & 341 & dis. & 341 & dis. & - & - & - & - \\
\hline & RS & dis. & dis. & dis. & - & - & - & - & 1293 & dis. \\
\hline & BS & dis. & dis. & dis. & - & - & - & - & 1078 & dis. \\
\hline & GL & - & - & - & dis. & dis. & - & - & - & - \\
\hline & RG & - & - & - & 1993 & dis. & - & - & - & - \\
\hline & $\mathrm{RE}$ & - & - & - & - & - & 1340 & 1340 & - & - \\
\hline & $\mathrm{CH}$ & - & - & - & - & - & - & - & 754 & 754 \\
\hline & HP & - & - & - & - & - & 1435 & 1435 & 729 & 729 \\
\hline & $\mathrm{HB}$ & - & - & - & - & - & - & - & - & - \\
\hline & EW & - & - & - & - & - & 302 & 302 & - & - \\
\hline & $\mathrm{IST}^{\# 3}$ & - & - & - & - & - & - & - & - & - \\
\hline & EWT $^{\# 3}$ & - & - & - & - & - & 2114 & 2114 & - & - \\
\hline & $\mathrm{HWT}^{\# 3}$ & 600 & 600 & 600 & 600 & 600 & 600 & 600 & 600 & 600 \\
\hline & \multicolumn{10}{|l|}{ Equipment installed newly } \\
\hline & GE & 341 & - & - & - & - & - & - & - & - \\
\hline & RS & 2780 & 1006 & - & - & - & - & - & - & - \\
\hline & BS & 3310 & 808 & - & - & - & - & - & - & - \\
\hline & GL & - & - & - & - & - & - & - & - & - \\
\hline & RG & - & 1598 & - & 841 & - & - & - & - & - \\
\hline & $\mathrm{RE}$ & - & - & - & - & - & - & - & - & - \\
\hline & $\mathrm{CH}$ & - & - & 887 & - & 887 & - & - & - & 352 \\
\hline & HP & - & - & 695 & - & 695 & - & 527 & - & 527 \\
\hline & $\mathrm{HB}$ & - & - & 457 & - & 457 & - & - & - & - \\
\hline & EW & - & - & 219 & - & 219 & - & - & - & 212 \\
\hline & $\mathrm{IST}^{\# 3}$ & - & - & 3199 & - & 3199 & - & - & - & - \\
\hline & EWT $^{\# 3}$ & - & - & 1532 & - & 1532 & - & - & - & 1484 \\
\hline & HWT & - & - & - & - & - & - & - & - & - \\
\hline
\end{tabular}


図 5 および表 6 に示したように，経済的に最適なケースは $H_{0}-H_{1}$ で，表 1 に示したように更新年 $t=\tau$ におい

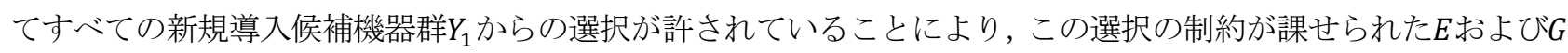
の方式のケースよりも論理的に優れていることを反映した結果である. また, 表 6 において, $S_{0}-E_{1}$ と $S_{0}-H_{1}, G_{0}-E_{1}$ と $G_{0}-H_{1}, E_{0}-E_{1}$ と $E_{0}-H_{1}$, および $H_{0}-E_{1}$ と $H_{0}-H_{1}$ のケースの最適解が, それぞれ等しいと いう結果は，注目に值する．なお， $3 \cdot 1$ 節で述べた $S_{0}-S_{1}$ という比較基準ケースの経済性は，一番劣っている.

次に, 表 6 において, $S_{0}-E_{1}, S_{0}-H_{1}, G_{0}-E_{1}$ おび $G_{0}-H_{1}$ のケースにおいて, 最適更新年はすべて $\tau^{*}=7$ [year] という結果になっている. 表 1 に示すように， $S_{0}$ おび $G_{0}$ の寸べての機器類はガス方式のものであり，上 記の結果は相対的にエネルギー効率の低い機器類を，できる限り早期の段階で高効率機器類に更新する方策を反 映したものである. 高効率な電気式機器類の設備単価は当然のことながら相対的には高いが, 図 5 および表 6 に 示すように年間総経費に占める設備費の割合は, 年間運用費, 寸なわち入力エネルギーおよび水道費と比較して 低く，上述の結果となっている．換言すれば，初期段階における高価な電気方式の機器類の導入の障害にはなっ

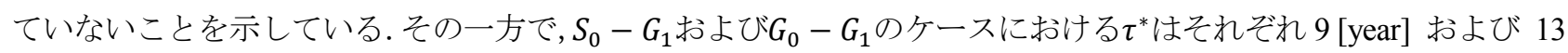
[year] で, $S_{0}$ および $G_{0}$ というガス方式システムに対しては, 新規のガス方式の機器類の導入を急いで行う必要は 無いという結果となっている. $H_{0}-E_{1}$ および $H_{0}-H_{1}$ のケースに関しては, $H_{0}$ はガスおよび電気方式の機器類を

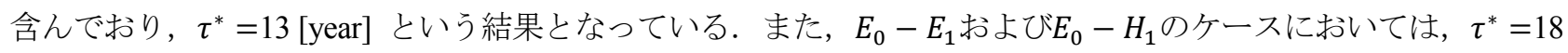
[year] であり, 高効率な機器類で構成される初期システム $E_{0}$ に対しては, 急いで更新を行う必要が無いことを示 している.さらに， $E_{0}-G_{1}$ および $H_{0}-G_{1}$ という両ケースに対しては，システムの評価期間内に更新を実施する 必要は無いという結果になっている. 換言すれば, 相対的に高効率な電気式初期システム $X_{0}=E_{0}$ は, ガス式シス テムに更新するのでは無く，できる限り長い期間使用する方策の方が，経済的に得策であることを示している.

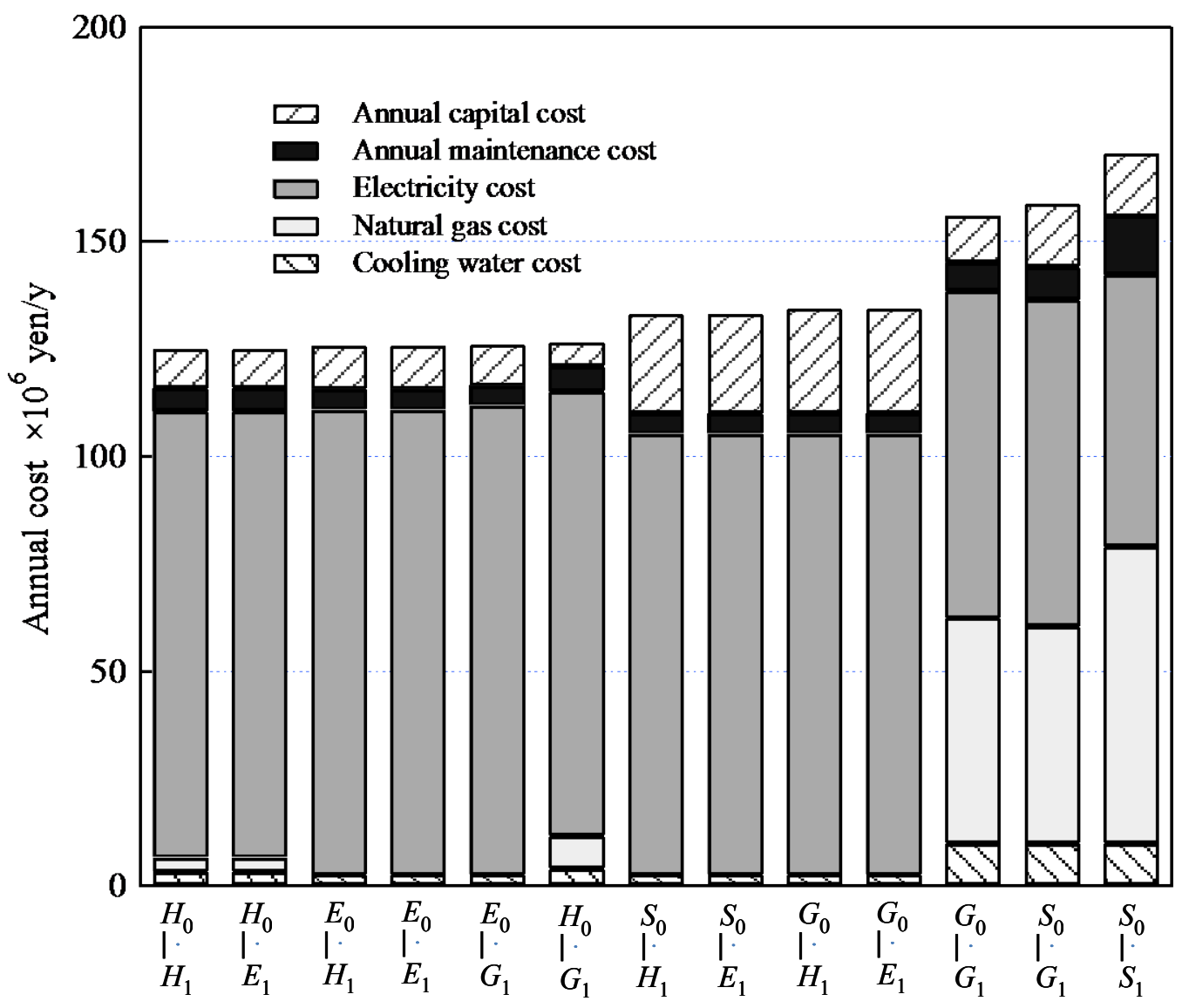

Fig. 5 Economic comparison of several renewal plans 


\section{4. 結}

本研究においては，建物におけるエネルギ一供給システムの長期的経済性を最小化しながら更新していくため の計画問題を，最適化法に基づいて検討した．上記問題は，一つの大規模な混合整数線形計画問題として定式化 され, AMPL/CPLEXにより最適数值解が導出された. 延床面積 $25000\left[\mathrm{~m}^{2}\right]$ 病院におけるエネルギー供給システ ムに対して，特に初期システムの更新計画に及ぼす影響に焦点を当て，スタンダード・ガス・電気および電気・ ガス併用式に関する更新計画問題の 13 ケースに対して比較分析・評価を実施した. その結果, 以下の主要な結果 が導出された.

(1) 初期システム $X_{0}$ の構成は，最適更新年 $t=\tau^{*}$ に大きく影響を及ぼす.

(2) 電気・ガス併用式システムは, 論理的に最適な更新システムである.ただし，本数值計算事例において は，電気・ガス併用式と電気式システムの経済性の面からの差は無い.

（3）初期システムがガス式の場合，ガス機器類の相対的効率の低さやガス料金体系の影響を反映して，より 効率的な電気式の機器類にできる限り早く更新する方策が，経済性の観点から有利である.

（4）初期システムが電気式の場合，更新を急いで実施する必要は低く，できる限り長期的に初期システムを 使用する方が良い。

（5）もし初期システムが電気式の場合，評価期間内にガス式に更新する必要性は存在しない.

なお最後に，電気・ガス併用式のシステムを採用した場合，システムの運用や制御，保守・点検などのメンテ ナンス面での複雑さが発生し，現実的に採用されるケースは少ないことを言及しておく．なお，今後の研究課題 として, 各種機器性能特性值の向上率および劣化率に関する感度分析を行っていく必要がある.

\section{謝 辞}

本研究の遂行に当り, 多大な御協力と御支援を頂いた建築電力懇話会総合エネルギー検討部会の各委員に深甚 の謝意を表します．また，本研究の一部は平成 24 年度科学研究費補助金基盤研究（C）（課題番号 24561062）の 支援を受けて行われたものである.

\section{文献}

(1) Yokoyama, R., Hasegawa, K., and Ito, K., “A MILP decomposition approach to large scale optimization in structural design of energy supply systems", Energy Conversion and Management, Vol. 43 (2002), pp. 771-790.

(2) Gamou, S., Ito, k., Yokoyama, R., and Yoshida, S., "Structural optimization of an energy supply system from economic viewpoint”, JSME International Journal, Series B, Vol. 47, No.2(2004), pp.173-179.

(3) Yoshida, S., Gamou, S., Ito, K., Enokido, T., and Yokoyama, R., "An optimal renewal planning of energy supply system from an economic viewpoint", In: Proceedings of International Conference on Power Engineering, Vol. B (2005), pp. 1477-1483.

(4) Yoshida, S., Inoue, M., Okano, A., Ito K., Amano, Y., and Hashizume, T., "Comparative study on renewal planning of alternative energy supply systems for a hospital”, In: Proceedings of Conference ECOS, (2011), pp. 150-157.

(5) Yoshida, S., Ito K., Amano, Y., Matsuo, K., Hashizume, T., and Ueta, K., “A multi-stage optimal renewal planning for energy supply system from an economic viewpoint”, In: Proceedings of International Conference on Power Engineering, Vol. 3 (2009), pp. 173-178.

(6) Amano, Y., Ito K., Yoshida, S., Matsuo, K., Hashizume, T., Favrat, D., and Marechal, F., "Impact analysis of carbon tax on the renewal planning of energy supply system for an office building”, Energy, Vol. 35 (2010), pp. 1040-1046.

(7) Yoshida, S., Ito, K., Amano, Y., and Hashizume, T., "Multi-objective optimal renewal planning of energy supply systems for buildings from economic and environmental viewpoints", In: Proceedings of ECOS, (2008), pp. 1545-1552.

(8) Witte, L. C., Schmidt, P. S., and Brown, D. R., Industrial energy management and utilization, (1988), pp.68-69, Hemisphere Pub.

(9) Adjiman, C. S., Schweiger, C. A., and Floudas, C. A., In: Du D.-Z., and Pardalos, P. M., editor. "Mixed-integer nonlinear optimization in process synthesis", Handbook of combinatorial optimization, Vol. 1(1998), pp. 1-76, Kluwer Academic Pub. 
(10) Robert, F., David, M. G., and Brain, W. K., AMPL:A modeling language for mathematical programming, Second ed. (2003), Thomson Brooks/Cole. 